\title{
Sustainable Livestock Development In The Border Of Merauke Region Based On Environment
}

\author{
Dirwan Muchlis ${ }^{1 *}$ and Nurcholis \\ ${ }^{1}$ Department of Animal Science, Faculty of Agriculture Musamus University, Merauke, Indonesia
}

\begin{abstract}
The purpose of this research is to provide information on sustainable livestock strategies with regard to the environment and social of Papua local communities in the process of cattle breeding process. In addition to increasing the productivity of local livestock, it is required the efficiency of the use of feed materials derived from agricultural waste. This policy should be supported with innovation and technology. Data collection method of this research using two types of data that is primary data and secondary data, primary data obtained from interviews of 30 breeders and the determination of respondents is conducted by way of purposive sampling. Secondary data were obtained from the Livestock Service Office of Merauke Regency, Department of Food Crops and Central Bureau of Statistics (BPS). The field survey results show that in addition to the field grass as the main feed, all breeders use agricultural waste as forage for livestock feed and use little palm oil waste. Types of agricultural waste used are rice straw, sweet potato straw, corn stalks and leaves, and groundnut straw. The highest agricultural waste production is corn stalk and leaves and banana waste both based on fresh produce and dry ingredients. In addition to the most common maintenance pattern is extensively and the best livestock development sites are in elikobel. Site selection based on various things such as location of topography, suboptimal land use, integration pattern optimization, developing local livestock such as poultry and pigs. The conclusion of this research is the strategy of development of sustainable livestock in border area can be conducted in elikobel district with various records such as the need of government policy related to environmentally careful livestock integration system, improving feed innovation and technology, livestock breeding, reproduction technology, and animal disease control to increase productivity and production of local livestock.
\end{abstract}

Keywords: Strategy; animal Science; environment.

\section{Introduction}

Merauke Regency consists of 20 districts and has 3 districts directly adjacent to the state of Papua new guinie. The districts are sota district, elikobel district, naukenjerai district. These three districts have different topography. Sota has a higher area with sloping terrain, while elikobel district is a bit hilly and high, naukenjerai district has lower and flat areas. These three districts are districts with a high number of cattle than the sloping land district, based on based on the Livestock Service Report of (2015). In addition, the cattle population in the Merauke Regency increases until 2017. The population of cattle reaches 36,919 cows, the number of poultry reached $1.931,000$ heads. This number is more than the population of Merauke of 248.000 inhabitants and most of the animals are in rural areas. Livestock productivity continues to increase despite having an environment (hot weather) and a maintenance system that is not yet optimal. Maintenance is not optimal due to the traditional pattern of community maintenance, because it is located in areas far from urban areas such as the three districts. The increase of livestock population in Merauke makes Merauke as one of the center of local livestock breeding production in eastern Indonesia based on the regulation through the Director
General of animal husbandry and animal health of 2016 which is based on the guidance of the implementation of the original / local beef cattle breeding in selected regency island in 2016 decision of the decision of the General Director of Animal Husbandry and Animal Health number: 619 / kpts / pk.210 / f / 03/2016 Date: March 1, 2016 stipulates that the Merauke Regency one of the native / local beef breeding reinforcement districts in the eastern region[1].

Sustainable livestock development certainly has many obstacles and challenges that are related to land resources, both for livestock and feed, about $33 \%$ of the land that can be planted for food crops used for feed (feedcrops) or as a whole about $70 \%$ of agricultural land [9]. Therefore, there is an alternative in managing animal feed, such as using agricultural waste and plantation. In addition, the availability of water should be noted that for the production of 1 ton of beef, it requires $3.900 \mathrm{~m}^{3}, 4,900 \mathrm{~m}^{3}$, and $15,500 \mathrm{~m}^{3}$ virtual water [2]. This program needs to get support from the government by conducting in-depth and comprehensive studies related to livestock breeding systems, livestock breeding, environmental factors related to feed, temperature, and maintenance patterns of local communities that need to be improved. The purpose of this research is to provide information on sustainable

* Corresponding author: muchlisdirwan@gmail.com 
livestock strategies by paying attention to the environment and local social community of Papua in the of cattle farming process. In addition to improve the productivity of local livestock, it is required the efficiency of the use of feed materials derived from agricultural waste and this policy should be supported with innovation and technology.contamination.

\section{Research Method}

Data collection method of this research using two types of data that is primary data and secondary data. Primary data obtained from the interviews of respondents 45 breeders each 15 breeders per district. Interviews were conducted using a questionnaire guide. The number of respondent breeders is determined based on the minimum number of samples in descriptive analysis $(\mathrm{n}=30)$ [7]. The determination of respondents is conducted by purposive sampling. Criteria for selecting respondents is a member of a cattle breeder group with ownership of at least three cows, chicken breeders with minimum ownership of 25 chickens and breeders who use agricultural waste as one source of forage feed. Secondary data were obtained from the Livestock Service Office of Merauke Regency, Department of Food Crops and Central Bureau of Statistics (BPS). Data analysis using descriptive method by data collecting, data compilation, and data depiction [4].

\section{Result and Discussion}

\section{Human Resource}

Population in three districts (elikobel, sota and naukenjerai) in border area according to (BPS, 2016) that is 4,053 people, 2,009 people and 13,878 people. Of this total, some breeders have education under junior high. The percentage of breeders based on the highest level of education is vocational high School / senior high school in the district soka of $10 \%$, followed by Naukenjerai $40 \%$ with the highest education junior high school. The level of education helps in understanding and improving selfpotential, including related to the breeding system. According to [6] the level of education plays an important role in understanding and applying farming technology. The breeding system in border communities is generally conducted in an extensive and traditional system. Understanding technology for breeders is closely related to education, but in addition to long-term breeding or experience can make farms able to receive the technology provided. Technology in the form of feed processing and feed preservation conducted by the livestock service and animal health of Merauke Regency in the form of counseling needs to be conducted intensively. According to [5] that the response of livestock farming communities to training and extension conducted by the livestock service is good. Inadequate maintenance system will be very difficult for breeders to control the health status of livestock, and optimal marriage system to produce superior livestock.

\section{Source of animal feed}

The field survey results show that in addition to field grasses such as Imperata cylindrica, calopogonium mucunoides, calopogonium caeruleum, Megathyrsus maximus as main feed, all breeders use agricultural waste as forages of livestock and use little palm oil waste. Types of agricultural waste used are sweet potato straw, corn stalks and leaves, and groundnut straw and rice straw. The percentage of grass and agricultural wastes as animal feeds in the three districts can be seen in Table 1. The highest production of agricultural waste as animal feed in the three districts is corn stalks and leaves both based on fresh produce and dry ingredients. Basically, agricultural waste will have high content of crude fiber that is good for cattle and goats. According to [8] fiber content $>18$ is good for ruminants feed. in addition to high fiber content kajar also some agricultural waste have high protein content that serves to increase the growth of livestock cells. According to [3] feed containing low protein can affect cell growth in cattle fetus.

Table 1. Production of agricultural waste as animal feed

\begin{tabular}{|c|c|c|}
\hline \multirow[t]{2}{*}{ District } & \multicolumn{2}{|c|}{ Type of animal feed } \\
\hline & Grass & Agricultural Waste \\
\hline Elikobel & $\begin{array}{l}\text { Imperata cylindrica, } \\
\text { calopogonium } \\
\text { mucunoides, calopogonium } \\
\text { caeruleum, Megathyrsus } \\
\text { maximus, } \\
\text { Brachiaria Decumbens, }\end{array}$ & $\begin{array}{l}\text { Palm oil bark, soybean straw, } \\
\text { groundnut straw, sweet } \\
\text { potato straw, coin straw, } \\
\text { green bean straw, banana } \\
\text { waste. }\end{array}$ \\
\hline Sota & $\begin{array}{lr}\text { Imperata } & \text { cylindrica, } \\
\text { calopogonium } & \\
\text { mucunoides, calopogonium } \\
\text { caeruleum, } & \text { Megathyrsus } \\
\text { maximus, } & \text { Urochloa } \\
\text { brizantha } & \end{array}$ & $\begin{array}{l}\text { Corn straw, sweet potato } \\
\text { straw, rice straw, groundnut } \\
\text { straw, green bean straw, } \\
\text { banana waste }\end{array}$ \\
\hline Naukenjerai & $\begin{array}{l}\text { Imperata cylindrica, } \\
\text { calopogonium } \\
\text { mucunoides,calopogonium } \\
\text { caeruleum, Megathyrsus } \\
\text { maximus }\end{array}$ & $\begin{array}{l}\text { Sweet potato straw, } \\
\text { groundnut straw, banana } \\
\text { waste. }\end{array}$ \\
\hline
\end{tabular}

Explanation: grass data is obtained from shepherd and feed given by breeders.

The highest results of waste in the three districts are corn stalk and leaves waste that is $34 \%$, followed by banana waste $21 \%$, and sweet potato waste $20 \%$. In addition to agricultural waste as ruminants feed, the main products such as corn are the main feed for poultry other than bran. Extensive maintenance system is also carried out with an integrated pattern with oil palm in elikobel district, but the less effective integration caused by young and unproductive oil palm plantations, so that the grass in the palm oil is cleared with herbicide. Utilization of feed technology should be developed to support continuous feed availability by utilizing agricultural waste as its main material.

\section{Availability of suboptimal land for livestock}

Livestock development also needs to pay attention to the available land. The available land area has an effect on the 
population density and the density of livestock. Density is important because available land cannot compete with community land. So far, livestock raising on the people's scale has no special land, so breeders use home yard for livestock raising. Therefore, the density of land to support the increase in the number of livestock still needs a solution. Table 2 shows the number of broiler densities, Ruminants livestock in three districts.

The density between community land and the number of livestock is very low. This is because the area of each district is quite high area such as Naukenjerai $905.86 \mathrm{~km}^{2}$, elikobel $1,666.23 \mathrm{~km}^{2}$ and sota $2,843.21 \mathrm{~km}^{2}$. The land that is not optimized as agricultural land can be used as traditional grazing area. Based on the extent of land and the availability of human resources and especially the availability of feed ingredients and grazing land, it can be concluded that the location of the best sustainable livestock development is elikobel district.

Table 2 The number of ruminant cattle densities in three districts.

\begin{tabular}{lccll}
\hline District & \multicolumn{2}{c}{ Density } & \multicolumn{2}{c}{ Density Status } \\
\cline { 2 - 5 } & $\begin{array}{c}\text { Ruminants } \\
\left(\mathrm{ST} / \mathrm{Km}^{2}\right)\end{array}$ & $\begin{array}{c}\text { Population } \\
\left(\mathrm{Jiwa} / \mathrm{Km}^{2}\right)\end{array}$ & $\begin{array}{l}\text { Ruminants } \\
\left(\mathrm{ST} / \mathrm{Km}^{2}\right)\end{array}$ & $\begin{array}{l}\text { Population } \\
\left(\mathrm{Jiwa} / \mathrm{Km}^{2}\right)\end{array}$ \\
\hline Elikobel & 72 & 2.43 & Low & Low \\
sota & 79 & 0.71 & Low & Low \\
Naukenjerai & 86 & 15.32 & Low & Low \\
\hline
\end{tabular}

Source: Central Bureau of Statistics Merauke Regency, Department of Animal Husbandry and Animal Health Merauke Regency, ST / $\mathrm{Km}^{2}$ : livestock unit per $\mathrm{km}^{2}$.

\section{Conclusion}

The conclusion of this research is the strategy of development of sustainable livestock in border area can be conducted in elikobel district with various records such as the need of government policy related to environmentally careful livestock integration system, improving feed innovation and technology, livestock breeding, reproduction technology, and animal disease control to increase productivity and production of local livestock.

\section{References}

1. Dirjen pembibitan dan produksi ternak. 2016. Pedoman pelaksanaan penguatan pembibitan sapi potong asli/lokal di pulau/ kabupaten terpilih tahun 2016. Dirjen Peternakan dan Kesmavet, Kementan. Jakarta.

2. Hoekstra, A.Y. and A.K. Chapagain. 2006. Water footprints of nations: Water use by people as a function of their consumption pattern. Water Res. Manag. 21: 35-48.

3. Maresca S, Valiente SOL, Rodriguez AM, Long NM , Pavan E, Quintans G. 2018. Effect of protein restriction of bovine dams during late gestation on offspring postnatal growth, glucose - insulin metabolism and IGF-1 concentration. Livestock Science. 1413(18)30105-7.

4. Mattjik AA, Sumertajaya M. 2000. Perancangan Percobaan. Jilid I. Bogor: IPB Press.

5. Nurcholis dan irine ike praptiwi. 2017. Efektivitas Pelatihan Pakan Alternatif Pada Ternak Sapi Di Musim Kemarau Bagi Masyarakat Kampung Sota Perbatasan RI/ PNG. Prosiding Semnas Persepsi II, Bali. 197 - 202.

6. Roessali, e. prasetyo, s. marzuki dan oktarian. 2005. pengaruh teknologi terhadap produktivitas dan pendapatan peternak sapi potong di desa canden kecamatan jetis kabupaten bantul. seminar nasional teknologi peternakan dan veteriner. 545 - 550 .

7. Sugiyono. 2011. Statistika untuk Penelitian. Bandung: Alfabeta.

8. Sukria HA, Krisnan R. 2009. Sumber dan Ketersediaan Bahan Baku Pakan di Indonesia. Bogor: IPB Press.

9. Steinfeld, H., P. Gerber, T. Wessenaar, V. Castel, M. Rosales, and C.de Haan. 2006. Livestock's Long Shadow: Environmental issues and option. FAO, Rome 